\title{
$\mathrm{Cu}-\mathrm{Sn}$ 合金の屈曲疲労特性に及ぼす結晶粒径と 錫濃度の影響
}

\author{
青山正義 ${ }^{1}$ 浦尾亮一2,* \\ ${ }^{1}$ 日立電線株式会社技術研究所 \\ 2 茨城大学工学部
}

J. Japan Inst. Metals, Vol. 74, No. 1 (2010), pp. 49-54

(C) 2010 The Japan Institute of Metals

\section{Effects of Grain Size and Sn Concentration on Bending Fatigue Life of Cu-Sn Alloy}

Seigi Aoyama ${ }^{1}$ and Ryouichi Urao ${ }^{2, *}$

${ }^{1}$ Research and Development Laboratory, Hitachi Cable, Ltd., Hitachi 319-1411

${ }^{2}$ Faculty of Engineering, Ibaraki University, Hitachi 316-8511

The effects of grain size and $\mathrm{Sn}$ concentration on the bending fatigue life of $\mathrm{Cu}-\mathrm{Sn}$ alloy were studied. Both the bending fatigue test and tensile test were conducted by using a $\mathrm{Cu}-\mathrm{Sn}$ alloy under 2.0 mass\% $\mathrm{Sn}$ with grain size being controlled by annealing. We found that the smaller the grain size, the longer the bending fatigue life of the $\mathrm{Cu}-\mathrm{Sn}$ alloy and the higher the $\mathrm{Sn}$ concentration in copper. A Long bending fatigue life for the $\mathrm{Cu}-\mathrm{Sn}$ alloy obtained by increasing of $0.2 \%$ Proof Stress involves three stress-dependent factors: grain size, friction stress and Hall-Petch constant. Friction stress and the Hall-Petch constant are functions of the Sn concentration in copper. Dislocation structures were found in cell structures after the bending fatigue test observed in Oxygen-free, high-conductivity copper, while the $\mathrm{Cu}-\mathrm{Sn}$ alloy revealed a uniform distribution structure of dislocation.

(Received April 3, 2009; Accepted October 1, 2009)

Keywords: grain size, copper-tin alloy, dislocation, annealing, micro structure, bending fatigue life

\section{1. 緒言}

銅合金は，強度，導電性，耐熱性，耐食性等に優れている ので, 電車線導電材料, 半導体電子材料, 熱交換器材料など に使用されている. 近年の電気電子機器の発展に伴いその用 途は多様化しており, パソコン, 携帯電話, ロボットや車両 ケーブルなど移動体機器向けに耐屈曲疲労特性に優れた銅合 金が望まれている1)。屈曲疲労特性に影響を及ぼす要因とし て，マクロ的因子である機械的特性，ミクロ的因子である結 晶粒径や屈曲疲労中に形成される転位構造等が考えられる. 現在まで疲労に関する多くの研究があり, 疲労機構, 疲労寿 命評価, 損傷評価などがある. その多くは鉄鋼材料で, アル ミ系材料や複合材もある ${ }^{2-4)}$. これに対して銅系材料の研究 として, $\mathrm{Cu}-\mathrm{Sn}$ 合金の加工度と疲労曲線の関係5), 銅単結晶 の転位構造6), $\mathrm{Cu}-\mathrm{Zn}$ 合金の $\mathrm{Zn}$ 濃度と微視的構造7)などの 研究があるが, 多結晶体の屈曲疲労現象を理解するには, 十 分とはいえない.

そこで, 耐屈曲疲労特性の基礎的研究として, 導電材料と して代表的な希薄 $\mathrm{Cu}-\mathrm{Sn}$ 合金を用いて，屈曲疲労寿命に及 ぼす結晶粒径の影響を系統的に明らかにしようとした。結果

\footnotetext{
* 茨城大学名誉教授(Emeritus Professor, Ibaraki University)
}

の一部は日本金属学会講演データ中に示した ${ }^{8)}$.

\section{2. 実 験 方 法}

供試材として $\mathrm{Cu}$ (OFHC: Oxygen-free, high-conductivity copper ), $\mathrm{Cu}-0.3$ mass $\% \mathrm{Sn}, \mathrm{Cu}-0.7$ mass $\% \mathrm{Sn}, \mathrm{Cu}-2.0$ mass $\% \mathrm{Sn}$ 合金を使用した。 まず，4 種類の試料を連続鋳造 機を用いて $5 \mathrm{~mm} \times 10 \mathrm{~mm}$ の平角材の形に鋳造した. 鋳造 材の $293 \mathrm{~K}$ に打導電率は, シグマテスタで測定し, $\mathrm{Cu}$ (OFHC) (102.5\% IACS), Cu-0.3 mass\% $\mathrm{Sn}(80.6 \% \mathrm{IACS})$, $\mathrm{Cu}-0.7$ mass \% $\mathrm{Sn}(65.5 \% \mathrm{IACS}), \mathrm{Cu}-2.0$ mass \% $\mathrm{Sn}(45.1 \%$ IACS)である. 試作した試料の化学分析結果を Table 1 に示

Table 1 Chemical composition of specimens (mass in ppm). Data marked with an asterisk $\left(^{*}\right)$ denotes mass\%.

\begin{tabular}{cccccccccccc}
\hline & $\mathrm{Sn}$ & $\mathrm{S}$ & $\mathrm{Fe}$ & $\mathrm{Ag}$ & $\mathrm{Bi}$ & $\mathrm{Ni}$ & $\mathrm{Pb}$ & $\mathrm{Si}$ & $\mathrm{As}$ & $\mathrm{Sb}$ & $\mathrm{O}$ \\
\hline $\begin{array}{c}\mathrm{Cu} \\
\mathrm{OFHC})\end{array}$ & $<1$ & 5 & $<1$ & 4 & 1 & $<1$ & $<1$ & $<1$ & $<1$ & $<1$ & 3 \\
\hline $\begin{array}{c}\mathrm{Cu}-0.3 \\
\mathrm{mass} \% \mathrm{Sn}\end{array}$ & $* 0.30$ & 5 & $<1$ & 4 & 1 & 1 & $<1$ & $<1$ & $<1$ & $<1$ & 3 \\
\hline $\begin{array}{c}\mathrm{Cu}-0.7 \\
\mathrm{mass} \% \mathrm{Sn}\end{array}$ & $* 0.70$ & 5 & $<1$ & 4 & 2 & 1 & $<1$ & $<1$ & 1 & $<1$ & 3 \\
\hline $\begin{array}{c}\mathrm{Cu}-2.0 \\
\mathrm{mass} \% \mathrm{Sn}\end{array}$ & $* 2.0$ & 6 & $<1$ & 4 & 3 & 1 & $<1$ & $<1$ & 4 & $<1$ & 3 \\
\hline
\end{tabular}


した。それらを厚さ $0.2 \mathrm{~mm}$ まで冷間圧延し 673〜 $1073 \mathrm{~K}$ で $1.8 \mathrm{ks}$ 焼なまして, 結晶粒径の調整をした. 結晶粒径は, JISH0501の伸銅品結晶粒度試験方法に沿って標準写真との 比較で評価した．即ち， $10 \mu \mathrm{m}$ 以下は $1 \mu \mathrm{m}$ の整数倍の值で 表示した. $10 \mu \mathrm{m}$ を超え $60 \mu \mathrm{m}$ 以下の場合には， $5 \mu \mathrm{m}$ の整 数倍に最も近い值とした. $60 \mu \mathrm{m}$ を超える場合, $10 \mu \mathrm{m}$ の 整数倍に最も近い值とした. 上記のような結晶粒径を調整し た試料から, 放電加工で引張試験用試験片および屈曲疲労試 験用試験片を切出した. 引張試験片は幅 $2 \mathrm{~mm}$, 厚さ 0.2 $\mathrm{mm}$, 標点距離 $25 \mathrm{~mm}$ である。これをひずみ速度 $1.33 \times$ $10^{-2} / \mathrm{s}$ の条件で試験し， $0.2 \%$ 耐力および引張強度と伸びを 測定した. 屈曲疲労試験片は, 幅 $2 \mathrm{~mm}$, 厚さ $0.2 \mathrm{~mm}$ であ る. 屈曲疲労試験は, 荷重 $1 \mathrm{~N}$ (応力 $24.5 \mathrm{MPa}$ )を負荷し, 試料表面に引張と圧縮の繰り返し曲げひずみを与える試験で ある. 表面の曲げひずみは, 試料の厚さ方向の中央が中立軸 であるとし, 中立軸から試料表面をでの長さを曲げの中心か ら中立軸までの長さで除した值である，以下曲げひずみと記 載してあるのはすべて表面曲げひずみを意味する．Fig. 1 は，屈曲疲労試験の方法を示したものである。試料は，(A) のように曲げ治具 (図中 RING と記載した)の間にセットし 荷重を負荷したまま，(B)のように治具が 90 度回転し曲げ を与える. この操作で, 曲げ治具に接している平角材表面に は，圧縮ひずみが，これに対応して裏側の表面には，引張ひ ずみが負荷される. その後, 再び $(\mathrm{A})$ の状態に戻る. 次に, (B)に示した向きと反対方向に 90 度回転し曲げを与える. この場合も, 曲げ治具に接している平角材表面には, 圧縮ひ ずみが，これに対応して裏側の表面には, 引張ひずみが負荷 され，(C)の状態になる.そして状態 $(\mathrm{C})$ から最初の状態 (A) に戻る. この屈曲疲労 1 サイクル $(\mathrm{A})(\mathrm{B})(\mathrm{A})(\mathrm{C})(\mathrm{A})$ に 要する時間は 4 秒である. 試料表面の一点に注目すると, 1 サイクルの間に圧縮ひずみと引張ひずみを受けることになる. 90 度曲げの際のひずみは, 曲げ治具の径を变えることによ り，曲げひずみを $0.99 \times 10^{-2} \sim 2.44 \times 10^{-2}$ の範囲で負荷し た. また, 屈曲疲労試験後の試料表面状況は, 走査型電子顕 微鏡 $(\mathrm{SEM})$ で観察した。屈曲疲労挙動を詳細に検討するた めに, $\mathrm{Cu}(\mathrm{OFHC}) の 573 \mathrm{~K}, 1.8 \mathrm{ks}$ の焼なをしを追加し, 結 晶粒径を $10 \mu \mathrm{m}$ に調整した。これにより, 結晶粒径 $10 \mu \mathrm{m}$ に調整した 4 種類の試料, 即ち $\mathrm{Cu}(\mathrm{OFHC}), \mathrm{Cu}-0.3$ mass $\%$ $\mathrm{Sn}(773 \mathrm{~K}, 1.8 \mathrm{ks}), \mathrm{Cu}-0.7$ mass$\% \mathrm{Sn}(823 \mathrm{~K}, 1.8 \mathrm{ks}), \mathrm{Cu}-2.0$

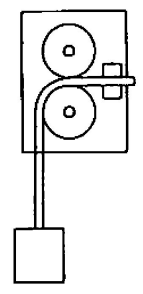

(B)

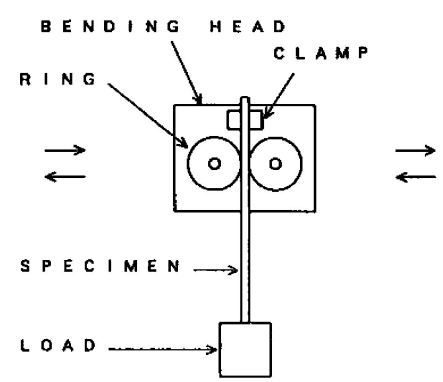

(A)

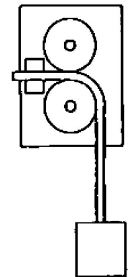

(c)
Fig. 1 Method of bending fatigue test. mass $\% \operatorname{Sn}(823 \mathrm{~K}, 1.8 \mathrm{ks})$ を得た.

これらの試料は, 屈曲疲労特性の比較, 屈曲疲労判断部近 傍の表面観察および屈曲疲労の際の微細組織観察等に供し た。微細組織観察は, $\mathrm{Cu}(\mathrm{OFHC})$ と $\mathrm{Cu}-0.7$ mass $\% \mathrm{Sn}$ を用 いて行った. それぞれの試料の屈曲疲労試験を途中で停止 し, 屈曲疲労した部分にひずみがかからぬように切出し, 燐 酸: 水 $=70: 30 \%$ にてシェット研磨し, 透過型電子顕微鏡 (TEM)により $200 \mathrm{kV}$ にて透過像の観察をした.

\section{3. 実験結果および考察}

屈曲疲労寿命に及ぼす結晶粒径の影響を掌握するために， まず, 焼なまし温度と結晶粒径の関係を測定し, Fig. 2 に示 した。これにより，所望の結晶粒径の試料を得ることができ た.

この図から $\mathrm{Cu}(\mathrm{OFHC})$ 抢よび $\mathrm{Cu}-\mathrm{Sn}$ 合金の結晶粒径は焼 なまし温度が高くなると大きくなることが分かる，合わせて， $\mathrm{Cu}(\mathrm{OFHC})$ の結晶粒径は $\mathrm{Cu}-\mathrm{Sn}$ 合金に比べて大きいことが 分かる．また，低温で焼なましをすると Sn 濃度が高いほど 結晶粒径は小さい。これは固溶 Sn 原子により結晶粒界の移 動が抑制されるためと思われる.

次に, 本研究の課題である結晶粒径と屈曲疲労寿命の関係 を明らかにするため, 試料に負荷した曲げひずみと破断まで の屈曲回数即ち屈曲疲労寿命 (以下屈曲疲労寿命と呼ぶ.) の 関係を求めた. Fig. 3 抢よび Fig. 4 にそれぞれ $\mathrm{Cu}(\mathrm{OFHC})$ および $\mathrm{Cu}-0.7$ mass \% Snの屈曲疲労試験結果を示した.

Fig. 3 に示す $\mathrm{Cu}(\mathrm{OFHC})$ の場合には, 結晶粒径が小さいほ ぞ屈曲疲労寿命が長いことが分る．Fig. 4 の $\mathrm{Cu}-0.7$ mass\% $\mathrm{Sn}$ の場合には, $\mathrm{Cu}(\mathrm{OFHC})$ と同様に結晶粒径が小さいほど 屈曲疲労寿命が長い. $\mathrm{Cu}(\mathrm{OFHC})$ と $\mathrm{Cu}-0.7 \mathrm{mass} \% \mathrm{Sn}$ を同 じ結晶粒径で比べると $\mathrm{Cu}-0.7$ mass\% $\mathrm{Sn}$ 合金は $\mathrm{Cu}(\mathrm{OFHC})$ より長い屈曲疲労寿命を示している.これらの結果を， $\mathrm{Cu}-$ $\mathrm{Sn}$ 合金の結晶粒径と破断までの曲げ回数の関係にまとめ,

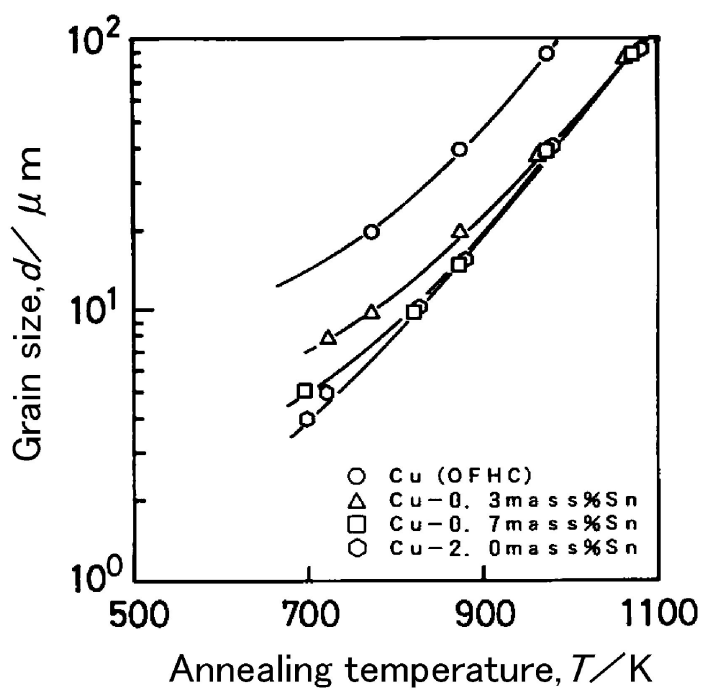

Fig. 2 Changes in grain size as a function of annealing temperature of $\mathrm{Cu}$ (OFHC) and $\mathrm{Cu}-\mathrm{Sn}$ alloy. The annealing time of specimens is $1.8 \mathrm{ks}$. 
Fig. 5 に示した.ここで, 屈曲疲労寿命の評価に結晶粒径の 平方根の逆数を採用しているのは, 以下に述べる HallPetchの式による考察を想定しているからである.

一般的に平滑材の疲労強度は降伏応力あるいは引張強度, 硬さの増大とともに上昇することが知られている. このよ うに疲労現象は, 塑性変形によるものと理解されている. 本 研究の屈曲疲労現象も疲労と同様に塑性変形のし易さに関係 することは予想される. 屈曲疲労寿命が銅中の Sn 濃度と結 晶粒径に影響されることが明らかになったので, 以下に示す Hall-Petchの式10-12)にて，屈曲疲労寿命に及ぼす Sn 濃度お よび結晶粒径の影響等を考察する.

$$
\sigma_{y}=\sigma_{0}+K_{\mathrm{f}} / \sqrt{d}
$$

ここで， $\sigma_{y}$ は塑性変形の尺度である降伏応力である． $\sigma_{0}$ は結晶粒の大きさに依らない部分で転位の動く摩擦力とみな されている. $d$ は結晶粒の平均直径， $K_{\mathrm{f}}$ は結晶粒の大きさ に依存しない材料定数 (Hall-Petch 定数)である ${ }^{12)}$ 。まず, 塑性変形の尺度の 1 つであり工業的に強度の指標として使 われる引張強度に関して検討した. Fig. 6 は $\mathrm{Cu}(\mathrm{OFHC})$ と $\mathrm{Cu}-\mathrm{Sn}$ 合金について, Hall-Petchの式の要素でもある結晶 粒径の平方根の逆数と引張強度の関係を示したものである.

結晶粒径が小さく $\mathrm{Sn}$ 濃度が高いほど高い引張強度を示 す。しかし, 破断までの大きな塑性変形量に相当する引張強 度と結晶粒径の平方根の逆数の間には, 測定したデータに直

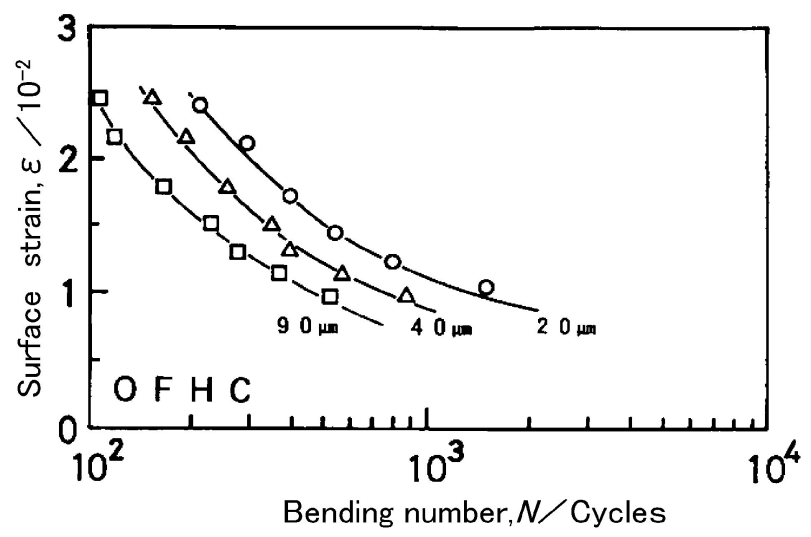

Fig. 3 Changes in bending fatigue life of $\mathrm{Cu}(\mathrm{OFHC})$ as a function of grain size.

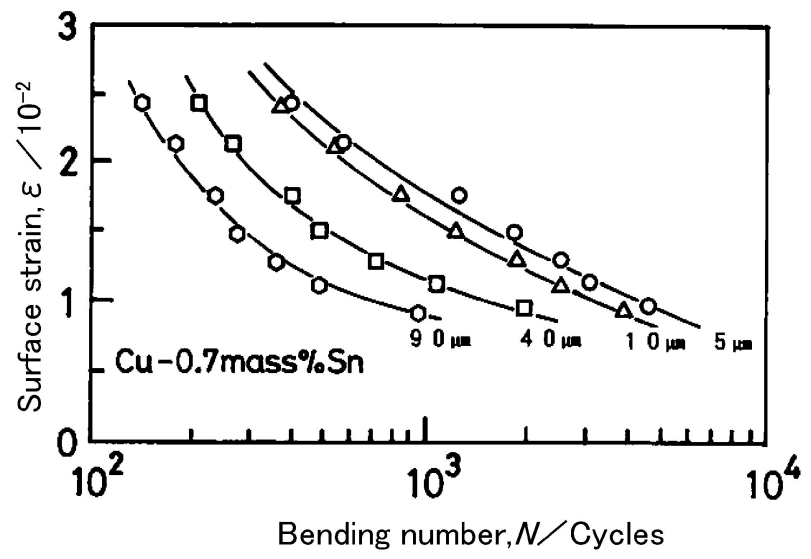

Fig. 4 Changes in bending fatigue life of $\mathrm{Cu}-0.7$ mass $\% \mathrm{Sn}$ alloy as a function of grain size.
線関係は無く, Hall-Petchの式の関係が成立してはいな い。詳細に見ると結晶粒径が大きくなると急激に引張強度が 低い值を示していることが分る，既に，塑性加工したひずみ 量が大きくかつ結晶粒径が大きい場合の塑性加工挙動につい ては, Fujita, Miyazaki, Shibata13-14) により, 試料の厚さと 結晶粒径の比をパラメータとしての流動応力の変化が検討さ れている. 99.99 mass\%純銅に関して, 結晶粒径 $(65 \mu \mathrm{m})$ が 同じ場合，試料の厚さに関わらず，降伏応力は同等である が, 試料が薄い場合には降伏ひずみよりも高い負荷ひずみ量 ほど, 流動応力が低下する現象が確認されている14)。本実 験では, 試料厚さが $200 \mu \mathrm{m}$ であり, 結晶粒径が大きく試料 内結晶粒の数が少ないので, 流動応力の低下が予想された.

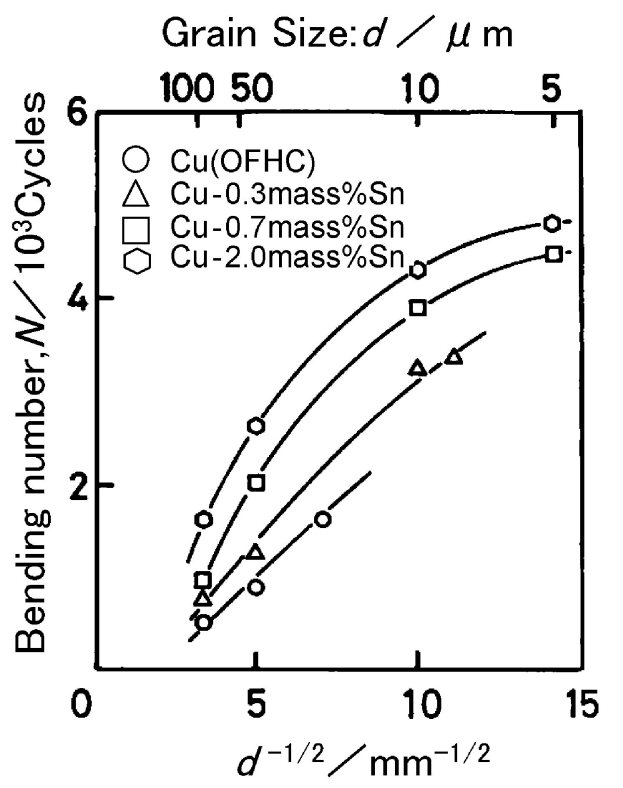

Fig. 5 Changes in bending fatigue life of $\mathrm{Cu}(\mathrm{OFHC})$ and $\mathrm{Cu}^{-}$ Sn alloy as a function of grain size. The bending surface strain is $1 \times 10^{-2}$.

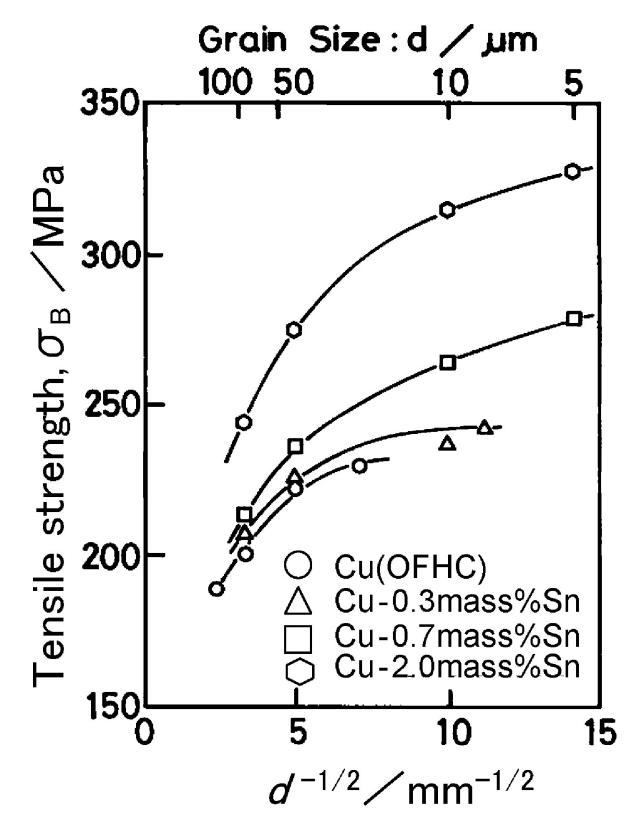

Fig. 6 Changes in tensile strength of $\mathrm{Cu}(\mathrm{OFHC})$ and $\mathrm{Cu}-\mathrm{Sn}$ alloy as a function of grain size. 
本実験結果では, 結晶粒が少なくかつ表面に出現している結 晶の割合が多いことにより，結晶粒同士の拘束力に依存する 多結晶体としての強度が得られていないものと考えられる。

次に, 屈曲疲労による亀裂が発生する塑性変形初期段階を 考えるために，試作した Sn 濃度の異なる試料の結晶粒径の 平方根の逆数と $0.2 \%$ 耐力の関係を Fig. 7 に示した．塑性变 形量の小さな $0.2 \%$ 耐力のひずみの領域では，本実験で検討 した範囲の $\mathrm{Cu}$ から 2.0 mass\% $\mathrm{Sn}$ を含む $\mathrm{Cu}-\mathrm{Sn}$ 合金まで, $0.2 \%$ 耐力と結晶粒径の平方根の逆数の間には, 明確な直線 関係があり，Hall-Petchの式が成立していることが分る. $0.2 \%$ 耐力は, 結晶粒径が大きくなるほど小さな值を示し, 結晶粒径が同じ場合では, Sn 濃度が高いほど大きな值を示 すことが分る。 $0.2 \%$ 耐力が Hall-Petchの式に適合するの は，塑性加工により導入されるひずみ量が引張強度を求める ときの破断ひずみに比べて少ないためと考えられる.ここで,

Fig. 7 に示した結晶粒径の関数で示される $0.2 \%$ 耐力のデー 夕を基に，結晶粒径を無限大に外挿することによって，転位 の動く摩擦力とみなしている $\sigma_{0}$ を求め, さらに結晶粒径の 平方根の逆数と $0.2 \%$ 耐力の直線性から，その傾き HallPetch 定数 $K_{\mathrm{f}}$ を算出した. これらの結果を，それぞれ Fig. 8 および Fig. 9 に示した. Fig. 8 は Sn 濃度と転位が動く抵 抗となる摩擦力の関係である. $1073 \mathrm{~K}$ に打ける $\mathrm{Sn}$ の固溶 限は 7.7 mass\%である15) から，Cu 中の Sn 濃度が 2 mass \% 以下の範囲の試料では, 酸素含有量が 3 mass ppm なので, 酸化物形成はほとんど無く Sn は固溶状態にある。結晶粒内 を転位の動く抵抗となる摩擦力 $\sigma_{0}$ は $\mathrm{Sn}$ 濃度の増加ととも に上昇している， $\mathrm{Cu}-\mathrm{Sn}$ 合金に扔いて，Sn 濃度が高くなる と屈曲疲労寿命が長くなる理由の一つは, 素材の摩擦力 $\sigma_{0}$ が高くなり, 結果として $0.2 \%$ 耐力が高くなるためである. 一方, Fig. 9 に示した Hall-Petch 定数 $K_{\mathrm{f}}$ も Sn 濃度が増加

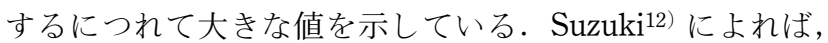
結晶境界が溶質原子で固着されているときには，原子の位置 を安定な位置からより高いエネルギーの位置に押し上げるこ とが多い。そのため，合金では転位が結晶粒界を通過すると きの抵抗が大きく， $K_{\mathrm{f}}$ が純金属に比べて大きくなるとされ ている．本研究でも同様に $K_{\mathrm{f}}$ に及ぼす固溶 $\mathrm{Sn}$ 原子の影響

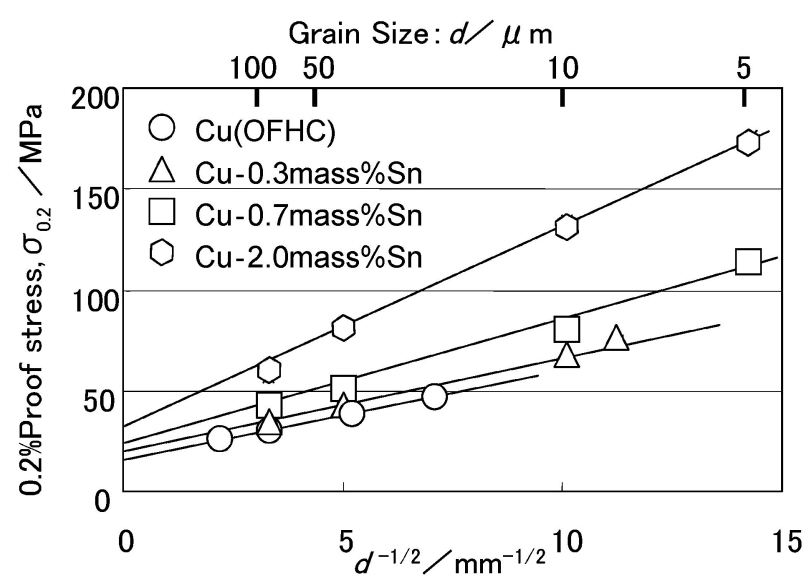

Fig. 7 Relation between $0.2 \%$ Proof stress, grain size of $\mathrm{Cu}$ (OFHC) and $\mathrm{Cu}-\mathrm{Sn}$ alloy as a function of $\mathrm{Sn}$ concentration.
が大きいものと推定される。これより $\mathrm{Cu}-\mathrm{Sn}$ 合金において, $\mathrm{Sn}$ 濃度が高くなると屈曲疲労寿命が長くなる理由の二つ目 は，素材の Hall-Petch 定数 $K_{\mathrm{f}}$ が高くなり，結果として $0.2 \%$ 耐力が高くなるためである. 理由の三つ目は結晶が細 かくなることによる，既に述べたように同じ温度で焼なまし た場合でも $\mathrm{Cu}-\mathrm{Sn}$ 合金は, $\mathrm{Cu}(\mathrm{OFHC})$ に比べて結晶粒径が 小さくなるためである.

以上の結果抢よび考察を踏まえて, 結晶粒径を一定に調整 して, 屈曲疲労寿命に及ぼす $\mathrm{Sn}$ 濃度の影響に関して微視的 組織観察をし, 考察する. Fig. 10 は結晶粒径を $10 \mu \mathrm{m}$ 一定 として，屈曲疲労寿命に及ぼす Sn 濃度の影響を示したもの である. Sn 濃度が高いほど屈曲疲労寿命が長いことが分か る. Fig. 11 は, Fig. 10 に示す Sn 濃度と屈曲疲労寿命の関

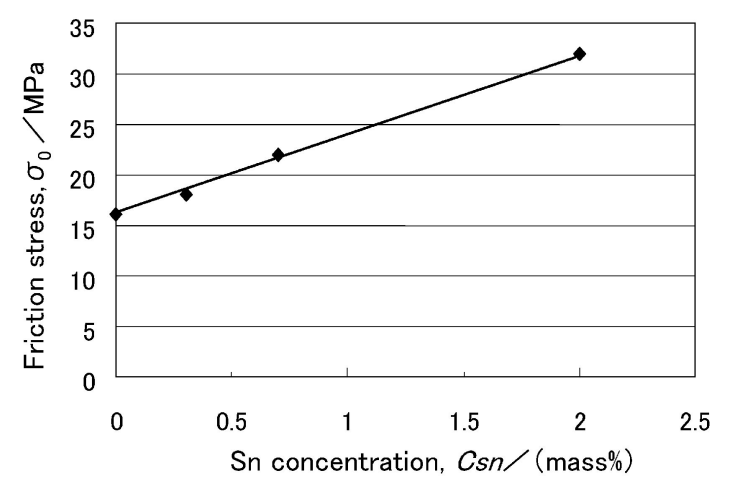

Fig. 8 Relation between friction stress and Sn concentration of $\mathrm{Cu}-\mathrm{Sn}$ alloy.

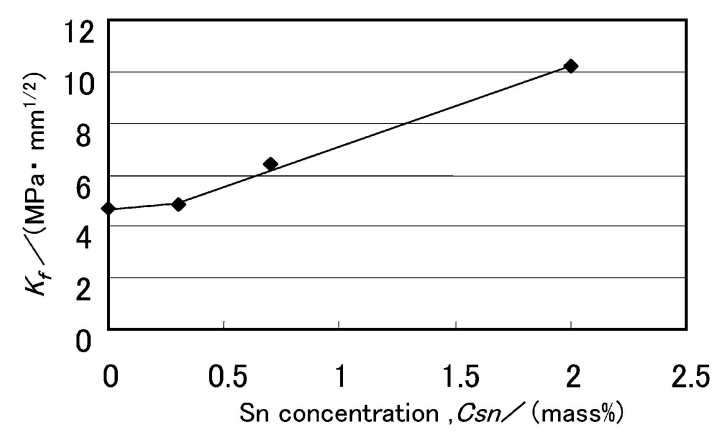

Fig. 9 Relation between Hall-Petch constant $K_{\mathrm{f}}$ and Sn concentration of $\mathrm{Cu}-\mathrm{Sn}$ alloy.

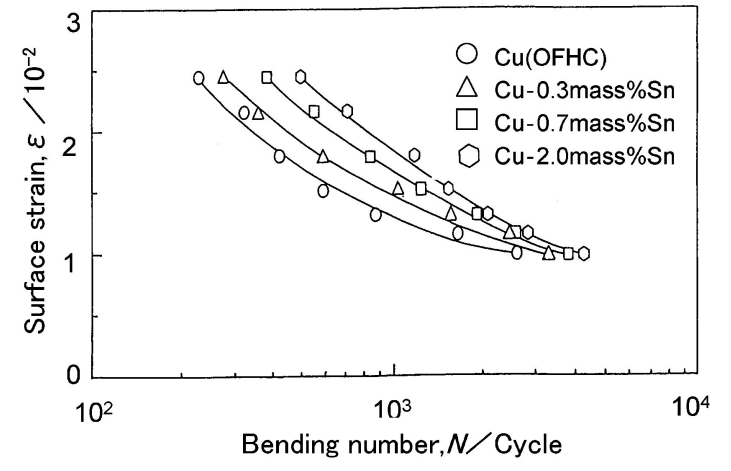

Fig. 10 Relation between bending surface strain and bending fatigue life of $\mathrm{Cu}(\mathrm{OFHC})$ and $\mathrm{Cu}-\mathrm{Sn}$ alloy with grain size of 10 $\mu \mathrm{m}$. 
(a)

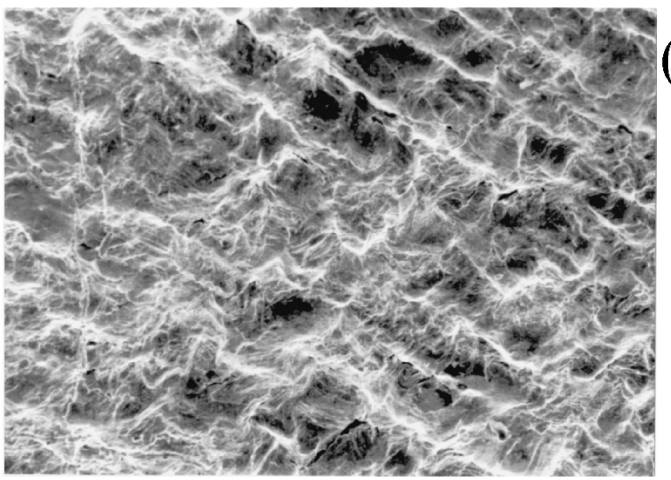

(b)

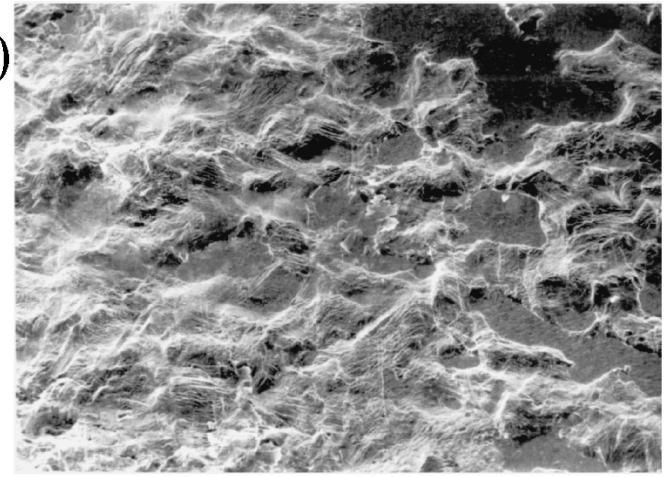

(c)

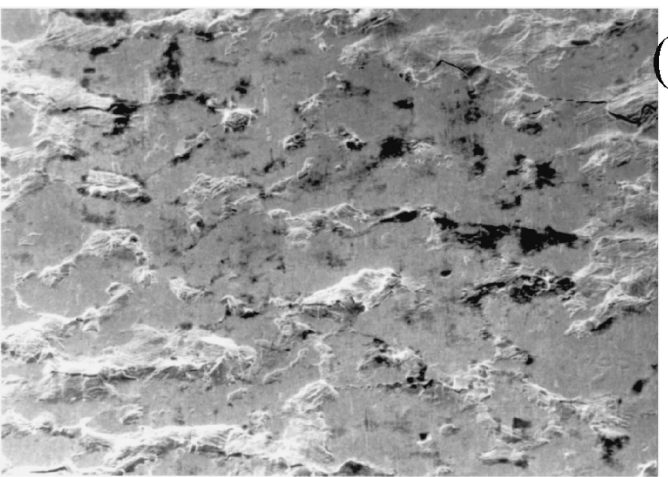

d)

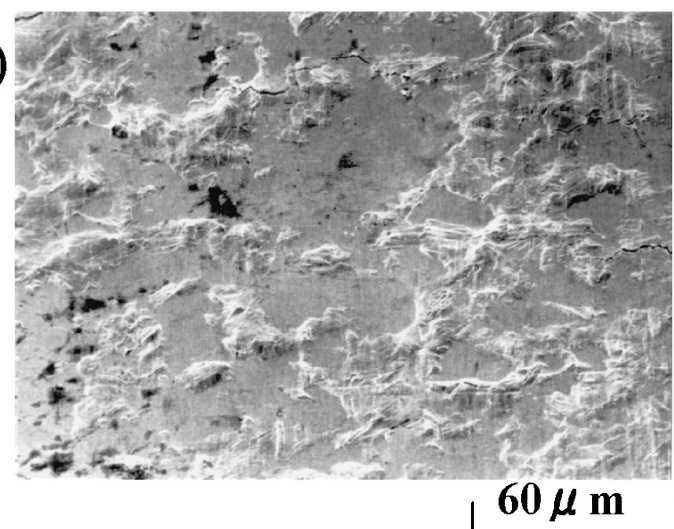

Fig. 11 SEM images on specimen surface near fractured surface. The grain size of samples is $10 \mu \mathrm{m}$. The surface strain is $1 \times 10^{-2}$. (a) $\mathrm{Cu}(\mathrm{OFHC})$, (b) $\mathrm{Cu}-0.3$ mass $\% \mathrm{Sn}$, (c) $\mathrm{Cu}-0.7$ mass $\% \mathrm{Sn}$, (d) $\mathrm{Cu}-2.0$ mass $\% \mathrm{Sn}$.

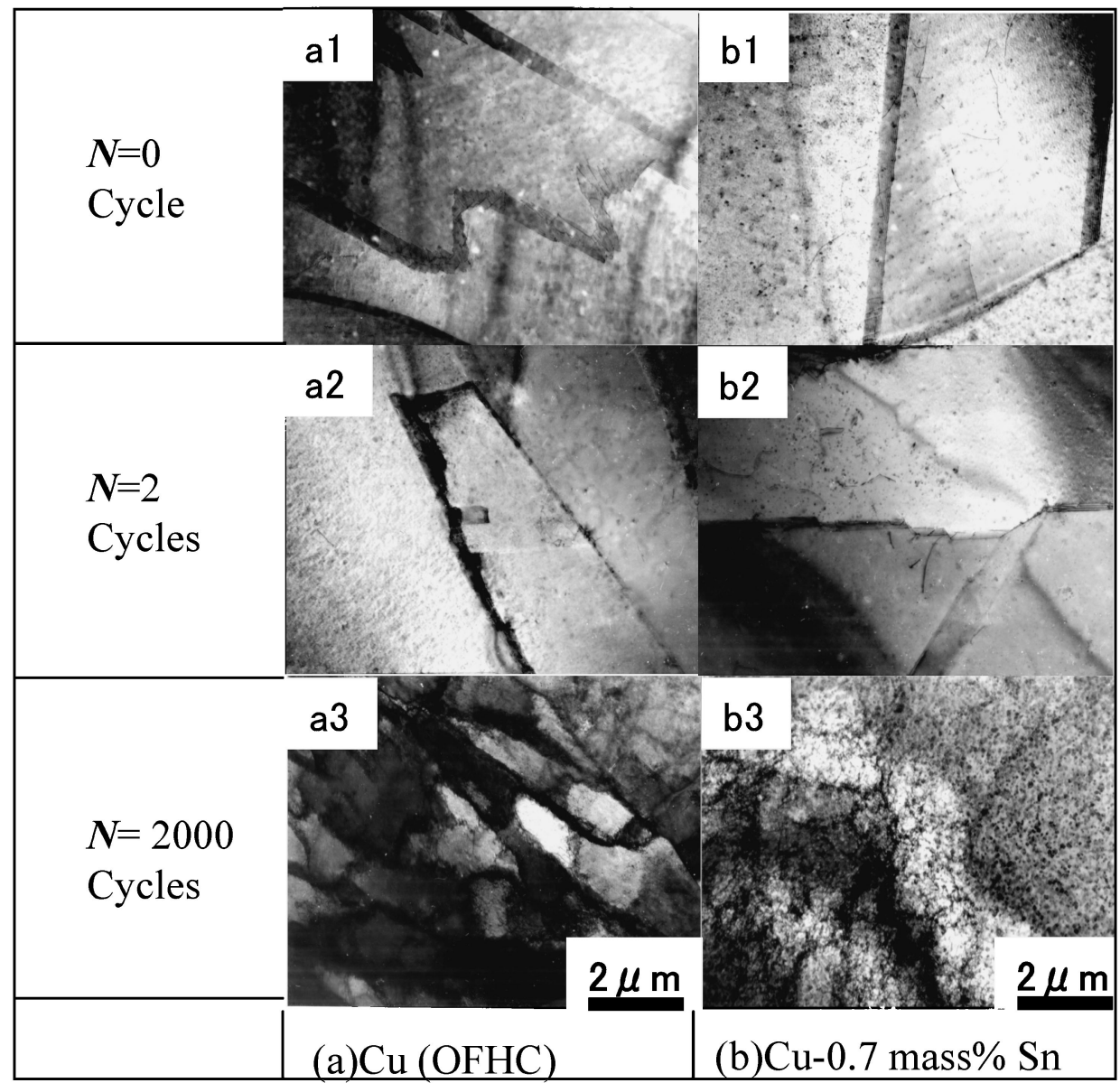

Fig. 12 Relation between TEM images of $\mathrm{Cu}(\mathrm{OFHC})$ and $\mathrm{Cu}-\mathrm{Sn}$ alloy with grain size of $10 \mu \mathrm{m}$ after bending fatigue test. The bending surface strain is $1 \times 10^{-2}$. Cu (OFHC): a1, a2, a3. Cu- 0.7 mass\% Sn: b1, b2, b3. $N$ : bending number (cycles). 
係において，表面曲げひずみを $1 \times 10^{-2}$ として，屈曲疲労 試験後の破壊部近傍の試料表面状況を観察したものである. $\mathrm{Cu}(\mathrm{OFHC})$ では，凹凸が全面的に観察された。これに対し， $\mathrm{Sn}$ 濃度が高い試料ほど表面の突き出し，入り込みの凹凸が 局所的に観察され，その量も少なくなっている。 また， $\mathrm{Cu}$ $(\mathrm{OFHC}), \mathrm{Cu}-\mathrm{Sn}$ 合金ともに試料表面の凹凸部にミク口的な 亀裂が観察された. 転位の動く抵抗となる摩擦力, 結晶粒径, Hall-Petch 定数 $K_{\mathrm{f}}$ から構成される $0.2 \%$ 耐力が高い $\mathrm{Cu}-\mathrm{Sn}$ 合金ほど凹凸が抑制され, 屈曲疲労寿命が長くなっているこ とが分かる。

Fig. 12 は, 結晶粒径が $10 \mu \mathrm{m}$ の場合, $\mathrm{Cu}(\mathrm{OFHC})$ と $\mathrm{Cu}-$ 0.7 mass \% Sn 試料に関して, 表面曲げひずみが $1 \times 10^{-2}$ の 場合に, 屈曲回数がゼロ回, 2 回, 2000 回で試験を止め, 屈曲疲労部の転位の入り方と構造を TEM で観察したもので ある。

わずか 2 回の屈曲疲労サイクルを経た $\mathrm{Cu}(\mathrm{OFHC})(\mathrm{a} 2)$ お よび Sn を含む銅合金 (b2)では，転位は少ないが，2000 回 の屈曲回数が多い場合は純銅 $(\mathrm{a} 3)$ 抢よび Sn を含む銅合金 (b3)の両方ともに明確に転位が増えていることが分かる. 詳細に見ると, $\mathrm{Cu}(\mathrm{OFHC})(\mathrm{a} 3)$ では，転位のセルが発達し ているのに対し，Snを含む銅合金(b3)では，転位のセルの 発達が抑制されており，発生した転位が写真に示されるよう に均一に全面に分布している.これより転位が固溶 Sn 原子 に固着され，塑性変形の抵抗になっていると考えられる.こ の結果は $\mathrm{Cu}-\mathrm{Al}$ 合金の疲労に打転位の挙動6) や $\mathrm{Cu}-\mathrm{Zn}$ 合金の疲労に及ぼす転位の挙動7) と同様に, 転位セルの発達 が少ないという共通して報告されている結果と同様な現象で ある.これらの TEM 像によるセルサイズや結晶粒界の観察 結果は, 試料の表面の観察から明らかになった凹凸のサイズ から見た分布状況と対応していた. 以上より $\mathrm{Cu}$ 中の $\mathrm{Sn}$ が 固溶する濃度範囲で， $\mathrm{Cu}$ に $\mathrm{Sn}$ を添加した $\mathrm{Cu}-\mathrm{Sn}$ 合金では， $\mathrm{Cu}(\mathrm{OFHC})$ に比べて塑性変形の抵抗が高くなり，屈曲疲労 寿命が長くなっていると判断される.

\section{4. 結言}

$\mathrm{Cu}-\mathrm{Sn}$ 合金の屈曲疲労特性に及ぼす結晶粒径と $\mathrm{Sn}$ 濃度の
影響を調べた。その結果，屈曲疲労寿命は，Sn 濃度が高く 結晶粒径が小さいほど長いことが分った。この屈曲疲労寿命 は $0.2 \%$ 耐力が高いほど長い。 $0.2 \%$ 耐力を高める因子は，(1) 結晶粒径, (2)転位の結晶粒内摩擦力, (3)Hall-Petch 定数で あることが分った。ここで, 転位の摩擦力と Hall-Petch 定 数は, Sn 濃度の関数になっている. 微細組織観察の結果, $\mathrm{Cu}(\mathrm{OFHC})$ に $\mathrm{S}$ を添加すると, 屈曲疲労試験によりその転 位の分布は変化し, 転位のセルが発達した $\mathrm{Cu}$ 組織から転位 が均一に全面に分布した $\mathrm{Cu}-\mathrm{Sn}$ 微細組織に変化することが 分った.

本実験と解析に協力された茨城大学学生 辻岡勝氏, 元日 立電線研究所市川貴朗氏に感謝致します。 また, 本論文 データに関し, 討論とご助言を頂きをした菅野幹宏東京大学 名誉教授, 東京大学 小関敏彦教授, 茨城大学 伊藤吾朗教授 に感謝致します。

\section{文献}

1) S. Aoyama: Hitachi Cable 26(2007) 1-10.

2) The Japan Society of Mechanical Engineers: Hirousekkeibinran, (Yokendo, 1995) pp. 1-5.

3) The Japan Society of Mechanical Engineers: Hirousekkeibinran, (Yokendo, 1995) pp. 355-361.

4) The Japan Society of Mechanical Engineers: Hirousekkeibinran, (Yokendo, 1995) pp. 380-383.

5) M. T. Jahn and A. R. Saavedea: J. Mater. Sci. 26(1991) 15961598.

6) C. E. Feltner and C. Laird: Acta Metall. 15(1967) 1633-1653.

7) P. Lukas and M. Klesnil: Phys. Status Solidi 21 (1967) 717-731.

8) T. Ichikawa, S. Aoyama, M. Tujioka and R. Urao: Collected Abstracts of the 1993 Spring Meeting of the Japan Inst. Metals, (1993) p. 185.

9) The Society of Materials Science, Japan: Dai25kai, Hiroukouza, Hirounokisotooyou, (November 17th, 2005) pp. 6-7.

10) E. O. Hall: Proc. Phys. Soc. (London) 64(1951) 747-753.

11) N. J. Petch: J. Iron Steel Inst. 174(1953) 25-28.

12) H. Suzuki: Kinzokunotuyosa, (Kaitei 1 han), (1981) AGNE, p. 197.

13) H. Fujita and S. Miyazaki: Acta Metall. 26(1978) 1273-1281.

14) S. Miyazaki, K. Shibata and H. Fujita: Acta Metall. $27(1979)$ 855-861.

15) M. Hansen and K. Anderrko: Constitution of Binary Alloys, Second Edition, (McGraw-Hill, New York, 1958) p. 634. 